\title{
Brief Report \\ Emergence of Macrolide-Resistant Mycoplasma pneumoniae during an Outbreak in a Primary School: Clinical Characterization of Hospitalized Children
}

\author{
Daniel Hubert ${ }^{1}$, Roger Dumke ${ }^{2}$, Stefan Weichert ${ }^{1}$, Sybille Welker ${ }^{3}$, Tobias Tenenbaum ${ }^{1, *},+(\mathbb{D}$ and \\ Horst Schroten 1,+ \\ 1 Pediatric Infectious Diseases, University Children's Hospital Mannheim, Heidelberg University, \\ 68167 Mannheim, Germany; daniel.hubert@gmx.de (D.H.); Stefan.Weichert@umm.de (S.W.); \\ Horst.Schroten@umm.de (H.S.) \\ 2 TU Dresden, Institute of Medical Microbiology and Hygiene, 01307 Dresden, Germany; \\ roger.dumke@tu-dresden.de \\ 3 Institute for Medical Microbiology and Hygiene, Medical Faculty Mannheim, Heidelberg University, \\ 68167 Mannheim, Germany; Sybille.Welker@umm.de \\ * Correspondence: Tobias.tenenbaum@medma.uni-heidelberg.de; Tel.: +49-621-383-2324; Fax: +49-621-383-3818 \\ $+\quad$ These senior authors contributed equally to this article.
}

check for

updates

Citation: Hubert, D.; Dumke, R.; Weichert, S.; Welker, S.; Tenenbaum, T.; Schroten, H. Emergence of Macrolide-Resistant Mycoplasma pneumoniae during an Outbreak in a Primary School: Clinical Characterization of Hospitalized Children. Pathogens 2021, 10, 328 https://doi.org/10.3390/ pathogens 10030328

Academic Editor: Steven L. Zeichner

Received: 24 February 2021

Accepted: 8 March 2021

Published: 10 March 2021

Publisher's Note: MDPI stays neutral with regard to jurisdictional claims in published maps and institutional affiliations.

Copyright: (C) 2021 by the authors. Licensee MDPI, Basel, Switzerland. This article is an open access article distributed under the terms and conditions of the Creative Commons Attribution (CC BY) license (https:/ / creativecommons.org/licenses/by/ $4.0 /)$.

\begin{abstract}
Mycoplasma pneumoniae (M. pneumoniae) is a common causative pathogen of communityacquired pneumonia. Here, we report the development of macrolide resistance during a school outbreak of severe M. pneumoniae infections in southwest Germany. We conducted a case series to assess the clinical and laboratory characteristics of hospitalized children with M. pneumonia infection and the prevalence of macrolide-resistant M. pneumoniae (MRMP) in this patient group. We retrospectively analyzed 23 children with serologically (19 patients) and/or PCR (eight patients) confirmed M. pneumoniae infection between October 2019 and December 2019. Most of the 15 hospitalized patients had lower respiratory tract infection $(\mathrm{n}=10)$ and required oxygen therapy (83\%). The median length of hospitalization was 7 days (range 3-10 days). In 8/15 patients (53.3\%) azithromycin and in $4 / 15(26.6 \%)$ clarithromycin treatment was applied. However, among the five patients for which extended molecular characterization was performed, sequencing of $23 \mathrm{~S}$ rRNA revealed no mutation only in the first case, but development of macrolide resistance A2058G in four subsequent cases. Hence, we identified a cluster of hospitalized patients with emerging MRMP. Further studies are warranted to confirm a potential link between macrolide resistance and disease severity.
\end{abstract}

Keywords: Mycoplasma pneumoniae; outbreak; children; macrolide resistance

\section{Introduction}

Mycoplasma pneumoniae (M. pneumoniae) is one of the most common pathogens causing community-acquired pneumonia (CAP) worldwide, responsible for up to $40 \%$ of cases in the general population during epidemic periods. Severe infections occur in children above 5 years of age, whereas younger children often present with a milder clinical course [1,2].

For treatment, tetracyclines and quinolones are not primarily recommended in children due to potential side effects, leaving macrolides as first therapeutic option [1,2]. The prevalence of macrolide-resistant M. pneumoniae (MRMP) varies from low levels in Europe (Germany: 3\%) to high rates in Asia (China: up to 100\%) [3,4].

\section{Results}

During the observational period, overall, 23 children presented either serologically (19 patients) and/or PCR (eight patients) confirmed M. pneumoniae infections. Of these 23 children, 15 were hospitalized. Patients (12/15) suffering from pulmonary symptoms were 
subsequently further analyzed (Table 1 ). Specific IgM was detected in 9/9 serologically tested patients, PCR was positive in $6 / 8$ patients, and positive serology and PCR were found in $2 / 5$ simultaneously tested patients (Table 2).

Of the 12 patients suffering from pulmonary symptoms, 10 were female and two were male. The median age was 8 years (range $3-10$ years). Ten cases $(83 \%)$ needed oxygen, one additionally required a high-flow nasal cannula. In these 10 cases with clinical signs of pneumonia ( $83 \%$ ), chest $\mathrm{X}$-rays were performed and radiological signs of pneumonia were detected in eight cases $(80 \%)$. Two patients $(20 \%)$ with oxygen demand had only clinical signs of pneumonia (tachypnea, crackles). The median period of oxygen supplementation was 6 days (range 3-9 days) and the median period of hospitalization was 7 days (range 4-10 days).

Patients with pulmonary symptoms were either treated with azithromycin in eight cases $(66 \%)$ or with clarithromycin in four cases $(33 \%)$. A positive test result for M. pneumoniae led to a change of antibiotic therapy in four patients, who had been initially treated with $\beta$-lactam antibiotics. The first patients with the confirmed wild-type M. pneumoniae strain were treated initially with azithromycin.

Overall, seven of eight PCR-positive samples were retrospectively sent to the national reference center for further analysis. In two specimens, PCR amplifications were negative; the remaining five underwent extended molecular characterization. The strains were identical concerning all described typing approaches (P1-, VNTR-, MLST- and SNP-type), suggesting that the outbreak was monoclonal (Table 3). Infection of the first inpatient from our observed cluster proved to be due to a macrolide-sensitive wild-type M. pneumoniae strain according to the $23 \mathrm{~S}$ rRNA sequencing analysis. This changed in the following patients, where an identical nucleotide exchange associated with resistance (A2058G; Escherichia coli (E. coli) numbering) could be identified.

No specific outbreak control measures were applied, since case incidence decreased spontaneously. Local health authorities and local outpatient pediatricians were asked to be alert to identify further MRMP infections. 
Table 1. Clinical characteristics of M. pneumoniae infections.

\begin{tabular}{|c|c|c|c|c|c|c|c|c|c|c|c|c|c|c|c|}
\hline Case & $\begin{array}{c}\text { Day of } \\
\text { Admission }\end{array}$ & $\begin{array}{c}\text { Age } \\
\text { (months) }\end{array}$ & Gender & $\begin{array}{c}\text { Symptoms } \\
\text { Before } \\
\text { Admission in } \\
\text { Days }\end{array}$ & $\begin{array}{l}\text { Temperature } \\
\text { in }{ }^{\circ} \mathrm{C}\end{array}$ & Imaging & $\begin{array}{c}\text { Imaging } \\
\text { Result }\end{array}$ & $\begin{array}{c}\text { Oxygen } \\
\text { Required } \\
\text { in Days }\end{array}$ & $\begin{array}{l}\text { Hospitalization } \\
\text { Duration in } \\
\text { Days }\end{array}$ & $\begin{array}{c}\text { Antibiotic } \\
\text { Treatment Before } \\
\text { Admission in Days }\end{array}$ & $\begin{array}{l}\text { If Yes, Which } \\
\text { Antibiotics? }\end{array}$ & $\begin{array}{l}\text { Antibiotic } 1 \text { in } \\
\text { Hospital }\end{array}$ & $\begin{array}{l}\text { Antibiotic } 2 \text { in } \\
\text { Hospital }\end{array}$ & $\begin{array}{l}\text { Discharge } \\
\text { Diagnosis }\end{array}$ & Comments \\
\hline 1 & 11.10 .2019 & 94 & $\mathrm{f}$ & 10 & 36.4 & chest $\mathrm{X}$-ray & pneumonia & 9 & 10 & no & & Azithromycin & no & pneumonia & \\
\hline 2 & 17.10.2019 & 88 & $\mathrm{f}$ & 9 & 40.3 & chest $X$-ray & pneumonia & 3 & 8 & no & & $\begin{array}{l}\text { Amoxicillin/ } \\
\text { Sulbactam }\end{array}$ & Azithromycin ${ }^{1}$ & pneumonia & $\begin{array}{l}\text { Minimal } \\
\text { pleural } \\
\text { effusion }\end{array}$ \\
\hline 3 & 01.11.2019 & 98 & $\mathrm{f}$ & 8 & 39.2 & chest $\mathrm{X}$-ray & pneumonia & 6 & 8 & 4 & Amoxicillin & Amoxicillin & Clarithromycin $^{1}$ & pneumonia & \\
\hline 4 & 02.11 .2019 & 100 & $f$ & 5 & 37.1 & chest $X$-ray & pneumonia & 5 & 6 & no & & Clarithromycin & no & pneumonia & \\
\hline 5 & 03.11.2019 & 125 & $\mathrm{f}$ & 9 & 37.3 & chest $X$-ray & pneumonia & 6 & 7 & 2 & Azithromycin & Azithromycin & no & pneumonia & \\
\hline 7 & 08.11.2019 & 55 & $\mathrm{~m}$ & 1 & 36.3 & chest $\mathrm{X}$-ray & $\begin{array}{c}\text { no } \\
\text { infiltrates }\end{array}$ & 2 & 6 & no & & $\begin{array}{l}\text { Amoxicillin/ } \\
\text { Sulbactam }\end{array}$ & Azithromycin ${ }^{1}$ & pneumonia & $\begin{array}{l}\text { Ventriculo- } \\
\text { peritoneal- } \\
\text { shunt }\end{array}$ \\
\hline 8 & 12.11.2019 & 38 & $\mathrm{f}$ & 7 & 37.2 & none & - & $\mathrm{n}$ & 3 & 1 & Erythromycin & Azithromycin & no & pneumonia & $\begin{array}{l}\text { Sibling had } \\
\text { pneumonia }\end{array}$ \\
\hline 9 & 14.11.2019 & 100 & $\mathrm{f}$ & 1 & 38.2 & chest $\mathrm{X}$-ray & pneumonia & 3 & 7 & no & & Azithromycin & no & pneumonia & \\
\hline 10 & 15.11.2019 & 143 & $\mathrm{~m}$ & 14 & 36.7 & MRI & normal & $\mathrm{n}$ & 3 & no & & no & no & neuritis & \\
\hline 11 & 16.11 .2019 & 105 & $\mathrm{f}$ & 8 & 37.2 & chest X-ray & pneumonia & 6 & 7 & 3 & Cefuroxim & Clarithromycin & no & pneumonia & \\
\hline 12 & 18.11.2019 & 115 & $\mathrm{f}$ & 7 & 38.5 & chest X-ray & $\begin{array}{c}\text { no } \\
\text { infiltrates }\end{array}$ & 6 & 7 & 3 & Azithromycin & no & no & $\begin{array}{c}\text { asthma } \\
\text { exacerbation }\end{array}$ & \\
\hline 14 & 30.11 .2019 & 63 & $\mathrm{~m}$ & 21 & 39.8 & none & - & $\mathrm{n}$ & 4 & no & & Ampicillin & no & pneumonia & \\
\hline 15 & 13.12.2019 & 16 & $\mathrm{~m}$ & 1 & 36.4 & none & - & $\mathrm{n}$ & 7 & no & & no & no & thrombocytopenia & $\begin{array}{c}\text { platelets } 8.000 \\
\left(10^{*} 9 / 1\right)\end{array}$ \\
\hline
\end{tabular}

${ }^{1}$ Antibiotic treatment was switched from 1st line treatment to 2 nd line antibiotic treatment after positive M. pneumoniae result was received. 
Table 2. Laboratory characteristics of M. pneumoniae infections.

\begin{tabular}{|c|c|c|c|c|c|c|c|}
\hline Case & $\begin{array}{c}\text { Leucocytes } \\
\left(10^{*} 9 / \mathrm{L}\right)\end{array}$ & $\begin{array}{c}\text { Neutrophils } \\
(\%)\end{array}$ & $\begin{array}{c}\mathrm{CRP} \operatorname{mg} / \mathrm{L} \\
(\max )\end{array}$ & $\begin{array}{l}\text { M. pneumonia } \\
\text { IgM }\end{array}$ & $\begin{array}{l}\text { M. pneumonia } \\
\text { IgA }\end{array}$ & $\begin{array}{l}\text { M. pneumonia } \\
\text { IgG }\end{array}$ & $\begin{array}{l}\text { M. pneumonia } \\
\text { PCR }\end{array}$ \\
\hline 1 & 8.180 & n.d. & 28.9 & n.d. & n.d. & n.d. & $\operatorname{pos}^{1}$ \\
\hline 2 & 10.350 & 81.2 & 22.7 & pos & neg & neg & $\operatorname{pos}^{1}$ \\
\hline 3 & 10.220 & 76.3 & 18.6 & pos & neg & 20 & $\operatorname{pos}^{2}$ \\
\hline 4 & 7.710 & 56.7 & 5.1 & pos & pos & 102 & neg \\
\hline 5 & 5.530 & n.d. & 15.9 & pos & pos & 34 & n.d. \\
\hline 6 & 7.540 & n.d. & 60.5 & pos & neg & neg & neg \\
\hline 7 & 10.270 & 53.6 & 71.8 & pos & neg & 26 & n.d. \\
\hline 8 & 15.620 & 64.4 & 49.2 & neg & neg & neg & pos $^{1}$ \\
\hline 9 & 16.140 & 78.8 & 29.1 & pos & neg & neg & n.d. \\
\hline 10 & 5.220 & n.d. & $<2.90$ & pos & neg & 49 & n.d. \\
\hline 11 & 9.730 & 73.4 & 39.3 & n.d. & n.d. & n.d. & pos $^{1}$ \\
\hline 12 & 5.420 & 71.5 & 16 & n.d. & n.d. & n.d. & $\operatorname{pos}^{1}$ \\
\hline 13 & 8.000 & 66.5 & 22 & pos & neg & 44 & n.d. \\
\hline 14 & 17.550 & n.d. & 51 & pos & pos & 94 & n.d. \\
\hline 15 & 17.760 & 48.2 & 7.8 & pos & neg & neg & n.d. \\
\hline
\end{tabular}

${ }^{1}$ In these cases, $23 \mathrm{~S}$ rRNA sequencing analysis was performed. ${ }^{2}$ Not enough PCR product available for further sequencing. Abbreviations: n.d. $=$ not determined, pos $=$ positive, neg $=$ negative,$C R P=C$-reactive protein . 
Table 3. Results of molecular characterization of M. pneumoniae strains.

\begin{tabular}{|c|c|c|c|c|c|c|c|c|c|c|c|c|c|c|c|c|c|c|c|c|c|c|c|c|c|}
\hline \multirow[t]{2}{*}{ Case } & \multirow[t]{2}{*}{$\begin{array}{c}\text { Age } \\
\text { (months) }\end{array}$} & \multirow[t]{2}{*}{$\begin{array}{l}\text { Macrolide } \\
\text { Resistance }\end{array}$} & \multirow[t]{2}{*}{$\begin{array}{c}\text { P1- } \\
\text { Type }\end{array}$} & \multicolumn{4}{|c|}{ VNTR-Typing } & \multicolumn{9}{|c|}{ MLST-Typing } & \multicolumn{9}{|c|}{ SNP-Typing } \\
\hline & & & & 13 & 14 & 15 & 16 & ppa & pgm & gyrB & gmk & glyA & $\operatorname{atpA}$ & $\operatorname{arcC}$ & adk & $\mathrm{ST}^{1}$ & gyrA & glpK & rpoB & rplB & gmk & 442 & 582 & P1 & SNP-Type \\
\hline 1 & 94 & Wild-type & 1 & 4 & 5 & 7 & 2 & 1 & 2 & 1 & 1 & 1 & 3 & 1 & 1 & 3 & A & A & G & $\mathrm{C}$ & A & A & A & G & 1 \\
\hline 2 & 88 & $\mathrm{~A} 2058 \mathrm{G}^{2}$ & 1 & 4 & 5 & 7 & 2 & 1 & 2 & 1 & 1 & 1 & 3 & 1 & 1 & 3 & A & A & G & C & A & $\mathrm{A}$ & A & G & 1 \\
\hline 8 & 38 & A2058G & 1 & 4 & 5 & 7 & 2 & 1 & 2 & 1 & 1 & 1 & 3 & 1 & 1 & 3 & A & $\mathrm{A}$ & G & $\mathrm{C}$ & A & A & A & G & 1 \\
\hline 11 & 105 & A2058G & 1 & 4 & 5 & 7 & 2 & 1 & 2 & 1 & 1 & 1 & 3 & 1 & 1 & 3 & A & $\mathrm{A}$ & G & $\mathrm{C}$ & $\mathrm{A}$ & A & A & G & 1 \\
\hline 12 & 115 & A2058G & 1 & 4 & 5 & 7 & 2 & 1 & 2 & 1 & 1 & 1 & 3 & 1 & 1 & 3 & A & A & G & C & A & A & A & G & 1 \\
\hline
\end{tabular}

1 Sequence type; 2 Overlap A/G. Abbreviations: VNTR = variable number of tandem repeats; MLST = multilocus sequence typing; SNP = single nucleotide polymorphism. 


\section{Discussion}

The M. pneumoniae strain found in the first investigated patient was sensitive to macrolides, whereas samples taken later during the outbreak from subsequent patients revealed macrolide resistance. To our knowledge, this is the first report about a macrolideresistant strain emerging during an outbreak in children. Development of resistance during antimicrobial treatment with macrolides has been reported for single patients [5]. Recently, a child with acute lymphoblastic leukemia and chronic M. pneumoniae carriage was reported to have a de novo macrolide resistance mutation (mix of A2058T and A2058G) and subsequent breakthrough pneumonia [6].

It has been previously discussed that MRMP may cause a more severe clinical course compared to macrolide-susceptible strains [7]. The pneumonia cases in our analysis were hospitalized longer than other cases we usually see in the respective age groups. All sequenced patients were previously healthy and had no macrolide treatment before. Therefore, we suspect either an increased virulence of the strains or that the inadequate treatment with macrolides led to delayed clinical improvement. Moreover, no extraordinary extended infiltrates nor pleural effusion could be detected in the chest X-rays. In a recent large school outbreak, an attack rate of $4 \%$ and an extended length of stay of patients in hospital for up to 4 weeks (median 11 days) were observed [8]. Pathogen characterization indicated that M. pneumoniae P1 type 1 was the causative agent during this outbreak and the strain harbored an exchange of $A$ to $G$ at position 2058, the most common point mutation in domain $\mathrm{V}$ of the $23 \mathrm{~S}$ rRNA. A recent meta-study showed that the duration of fever in patients infected with macrolide-resistant strains lasts 1.71 days longer and the length of stay is 1.61 days longer [9]. To date, no specific factor has been identified to predict the clinical course of disease, and no evidence supports the causal relationship between macrolide resistance and disease severity.

Due to the retrospective nature of the study, we neither could identify other potential "first" MRMP cases in the outpatient community nor track how many patients in the nearby outpatient community were treated with macrolides. Since the first patient with MRMP in our study cohort was found in October, other potential M. pneumoniae infections, either with wild-type or MRMP strains, may have already emerged in the community in September. However, unfortunately, due to a lack of active surveillance and patient material, potential macrolide resistance in these patients could not be further analyzed.

Finally, the necessity and efficacy of antibiotic therapy in M. pneumoniae infections is still under debate [9]. All our patients showed a clinical improvement despite proven macrolide resistance, indicating the self-limiting course of the disease. The potential anti-inflammatory effect of macrolides as well as of steroids may contribute to clinical improvement in infections with MRMP [10].

\section{Materials and Methods}

\subsection{Study Design and Participants}

Between October 2019 and December 2019, we observed a cluster of hospitalized pediatric patients with $M$. pneumoniae infections, who went to same primary school in Mannheim. Children with M. pneumoniae infection were identified either by serology (IgM/IgG; Institute Virion/Serion, Würzburg, Germany) and/or real-time PCR (FilmArray ${ }^{\circledR}$, Biofire ${ }^{\circledR}$, Nürtingen, Germany) for M. pneumoniae (nasopharyngeal swabs). In children for whom patient material was initially available, we analyzed for the presence of macrolide resistance via sequencing of $23 \mathrm{~S}$ rRNA (German reference center for mycoplasma, Dresden, Germany).

\subsection{Data Analysis}

Clinical and laboratory characteristics of hospitalized patients with M. pneumonia infections were retrospectively analyzed. Due to the small case numbers, a statistical analysis could not be conducted. Instead, a detailed case series description has been performed. 


\section{Conclusions}

Our study highlights the probable development of antimicrobial resistance of M. pneumoniae during an outbreak of severe cases of CAP among school children. Even in countries with a low rate of resistance, clinicians should be aware of the emergence of resistance of primarily susceptible strains and its potential contribution to the course of subsequent infections. Timely molecular characterization of MRMP strains can help to improve the efficiency of treatment.

Author Contributions: D.H., T.T. and H.S. conceptualized the work and wrote the manuscript. R.D., S.W. (Stefan Weichert) and S.W. (Sybille Welker) provided clinical and microbiological data and validated them. All authors have read and agreed to the published version of the manuscript.

Funding: This research received no external funding.

Institutional Review Board Statement: The study was conducted according to the guidelines of the Declaration of Helsinki, and approved by the Institutional Review Board (or Ethics Committee). The study protocol was submitted to the local ethical research committee according to the German law for medical research involving human subjects and approved (reference 2021-805).

Informed Consent Statement: Patient consent was waived due to the retrospective nature of the study.

Conflicts of Interest: The authors declare no conflict of interest.

\section{References}

1. Waites, K.B.; Xiao, L.; Liu, Y.; Balish, M.F.; Atkinson, T.P. Mycoplasma pneumoniae from the Respiratory Tract and Beyond. Clin. Microbiol. Rev. 2017, 30, 747-809. [CrossRef] [PubMed]

2. Beeton, M.L.; Zhang, X.S.; Uldum, S.A.; Bébéar, C.; Dumke, R.; Gullsby, K.; Ieven, M.; Loens, K.; Nir-Paz, R.; Pereyre, S.; et al. Mycoplasma pneumoniae infections, 11 countries in Europe and Israel, 2011 to 2016. Eurosurveillance 2020, 25, 1900112. [CrossRef] [PubMed]

3. Gullsby, K.; Olsen, B.; Bondeson, K. Molecular Typing of Mycoplasma pneumoniae Strains in Sweden from 1996 to 2017 and the Emergence of a New P1 Cytadhesin Gene, Variant 2e. J. Clin. Microbiol. 2019, 57. [CrossRef] [PubMed]

4. Bao, F.; Qu, J.X.; Liu, Z.J.; Qin, X.G.; Cao, B. The clinical characteristics, treatment and outcome of macrolide-resistant Mycoplasma pneumoniae pneumonia in children. Zhonghua Jie He He Hu Xi Za Zhi 2013, 36, 756-761. [PubMed]

5. Dumke, R.; Stolz, S.; Jacobs, E.; Juretzek, T. Molecular characterization of macrolide resistance of a Mycoplasma pneumoniae strain that developed during therapy of a patient with pneumonia. Int. J. Infect. Dis. 2014, 29, 197-199. [CrossRef] [PubMed]

6. Alishlash, A.S.; Atkinson, T.P.; Schlappi, C.; Leal, S.M., Jr.; Waites, K.B.; Xiao, L. Mycoplasma pneumoniae Carriage With De Novo Macrolide-Resistance and Breakthrough Pneumonia. Pediatrics 2019, 144. [CrossRef] [PubMed]

7. Atkinson, T.P.; Waites, K.B. Mycoplasma pneumoniae Infections in Childhood. Pediatr. Infect. Dis. J. 2014, 33, 92-94. [CrossRef] [PubMed]

8. Zhang, W.Z.; Zhang, S.J.; Wang, Q.Y.; Li, Y.D.; Jing, H.B.; Hu, G.Y.; Wu, D. Outbreak of macrolide-resistant mycoplasma pneumoniae in a primary school in Beijing, China in 2018. BMC Infect. Dis. 2019, 19, 871. [CrossRef] [PubMed]

9. Chen, Y.C.; Hsu, W.Y.; Chang, T.H. Macrolide-Resistant Mycoplasma pneumoniae Infections in Pediatric Community-Acquired Pneumonia. Emerg. Infect. Dis. 2020, 26, 1382-1391. [CrossRef] [PubMed]

10. Blyth, C.C.; Gerber, J.S. Macrolides in Children with Community-Acquired Pneumonia: Panacea or Placebo? J. Pediatr. Infect. Dis. Soc. 2018, 7, 71-77. [CrossRef] [PubMed] 